\title{
喉頭気管の再建における水酸化 アパタイトの利用
}

\author{
*平野 実，吉田 哲二 \\ 坂口 伸治, 伊東 敏雄
}

\section{Hydroxyl Apatite in Reconstruction of the Laryngotracheal Framework}

\author{
Minoru Hirano, M.D., Tetsuji Yoshida, M.D., Shinji Sakaguchi, M.D. \\ and Toshio Ito, M.D. \\ Department of Otolaryngology-Head and Neck Surgery, \\ Kurume University, School of Medicine, Kurume
}

\begin{abstract}
Hydroxyl apatite was employed in reconstruction of the laryngotracheal framework in five cases. It was well received in all the cases and there were no foreign body reactions or infections at all. The hydroxyl apatite proved to be an excellent material in reconstructing the laryngotracheal framework, being comparable to an autograft of the cartilage. The use of hydroxyl apatite saves additional surgery.
\end{abstract}

Key words : 喉頭気管再建, 喉頭気管狭窄, 水酸化アパタイト

\section{は じめに}

喉頭気管の狭窄や部分的組織欠損に対する手 術における大きな問題のひとつは，軟骨の枠組 をどのように再建するかである。従来，自家軟 骨や人工材料が用いられているが，良質の人工 材料があれば，余分の手術侵襲を要する自家軟 骨よりも好都合である。

最近われわれは，5例の喉頭気管の枠組みの 再建に水酸化アルパタイトを軟骨に代る支持組 織として用い，よい結果を得たので報告する。

\section{症例}

症例 1 ：N.H. 47歳 女性

初診：1983年 3 月 23 日

主訴：呼吸困難

現病歴：1980年 8 月 15 日，〈も膜下出血に罹

*久留米大学医学部耳鼻咽喉科学教室
患し，以後1981年 9 月30日までの間に某脳外科 医院において, drainage operation, neck clipping operation, shunt operation, など計 4 回 の手術を受けた。患者は意識がほとんどなく， 呼吸管理の必要があったため，1981年10月 2 日 気管切開術が施行された。同年12月30日より気 管カニューレを抜去し，気管孔を自然閉鎖させ た。 1 年 2 力月経過した 1983 年 2 月頃から軽い 呼吸困難が出現し徐々に増悪するため, 同年 3 月22日再び気管切開が施行された。そのとき， 気管の狭窄が疑われたので, 翌23日筑後市立病 院 (本学関連病院) 耳鼻咽喉科に紹介され転院 した。

所見, 治療, 経過 : 気管狭窄は, 気管孔の直 上に全周性に認められた(図 1 )。当時患者は運 動麻痺を有し, 常に失禁し, 発語も不能であっ た。しかし脳障害の程度が安定しており，時々 奇声ではあるが発声し，家族や医師の問いにわ 
日気食会報，38（1）, 1987

ずかではあるが反応し，また気管孔があいてい るとリハビリ施設が受け入れてくれないなどの 理由によって，気管孔を閉鎖する方針で治療を 計画した。

1984年 2 月 24 日気管孔を広く開大しなおし， 狭窄の原因となっていた肉芽を除去し，気管粘 膜と皮膚を縫合して気管開空の状態にした。

1985年 4 月24日気管の再建と閉鎖を行なっ た。気管孔の大きさは, 縦 $16 \mathrm{~mm}$, 横 $17 \mathrm{~mm}$ で あった。気管孔周囲の皮膚を hinge flap として 用い, 気管の前壁を作製した。その上に縦 18 $\mathrm{mm}$, 横 $15 \mathrm{~mm}$, 厚さ $2 \mathrm{~mm}$ の多孔体の外耳道 後壁用アパタイト（旭光学 B-1 type）を置いた。 アパタイトの中央部 2 カ所にダイヤモンドバー で穴をあけ，穴を通して気管前壁の皮弁をアパ タイトに縫着固定した。創は周囲の皮膚を引き よせて閉鎖した。

約 1 年経過した現在, 再狭窄の所見は全く認 めない。

症例 $2 ：$ K.S. 67歳 男性

初診：1981年10月22日

主訴：呼吸困難

現病歴：1981年 4 月頃より軽度の呼吸困難が あり, 近医で治療を受けたが軽快せず，同年 8 月頃より症状が増悪したので, 某病院内科と耳 鼻咽喉科を受診した。頸部腫瘤と気管左側壁の 腫瘤を指摘されて，当科を紹介された。

所見, 治療, 経過：1981年10月27日当科に入 院し, 甲状腺癌 T4N1M0 の診断のもとに, 11月 5 日甲状腺两全摘出術および左頸部郭清術を行 なった。この際，輪状軟骨より第 5 気管輪にわ たって, 前壁および左側壁を, 癌浸潤のために 切除した。欠損部では，粘膜と皮膚を縫合して 気管と喉頭の一部を樋状に開放した。

1982年 8 月23日，気管の左側壁を作製する目 的で，左鎖骨の一部を気管の左方に遊離移植し た。その時同時に左頸部郭清術も行なった。し かし移植した鎖骨が気管より外側方に寄りすぎ ていたため，気管孔の左側壁がポケット状とな り，痰がたまりやすくなってきた。

1984年10月 1 日，このポケット状の陥凹を充 填し，つぎの喉頭気管形成の準備をしておく目 的で, DP 皮弁で鎖骨の内側方の陥凹を充填し，

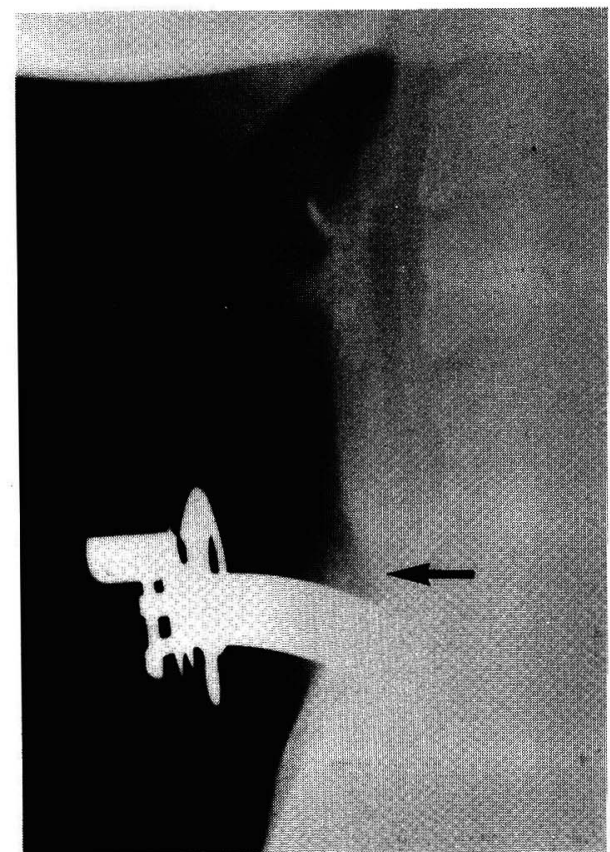

図 1 症例 1 の術前の頸部単純 $\mathrm{X}$ 線写真(側面) 矢印は気管カニューレ直上の肉芽による気管 狭窄の状態を示す。

気管左壁を形成した。

1985年 1 月21日，喉頭気管再建を行なった。 喉頭気管孔の大きさは繸 $40 \mathrm{~mm}$, 横 $15 \mathrm{~mm}$ で あった(図 $2 \mathrm{~A}$ )。気管左側方の DP 皮弁と右側 方の前頸部の皮膚を用いて，気管前壁を作製し た(図 $2 \mathrm{~B})$ 。その上に, 骨補填用の多孔体アパ タイト（旭光学 B-2 type）を置き，小孔を通し て前壁の皮弁と縫着固定した(図 $2 \mathrm{C}$ )。使用し たアパタイトの大きさは, 縦 $30 \mathrm{~mm}$, 横 20 $\mathrm{mm}$, 厚さ $7 \mathrm{~mm}$ である。創は DP 皮弁の残りを 用いて閉鎖したが，用心のため気管孔下部に直 径約 $5 \mathrm{~mm}$ の気管孔を開けておいた（図 $2 \mathrm{D}$ )。

1985年 6 月 6 日，狭窄がないこと，気管を閉 じても呼吸困難がおこらないことを確認した 後，気管孔を閉鎖した。閉鎖後約 9 力月を経過 した現在，再狭窄の所見は認められない。

症例 3 : K.I. 60 歳 女性

初診：1985年 1 月 8 日

主訴：前頸部腫瘤

現病歴：1953年 5 月に前頸部の腫瘤に気付い たが放置していた。その後腫瘤が徐々に増大し てきたため，1985年 1 月 8 日当科を受診した。 


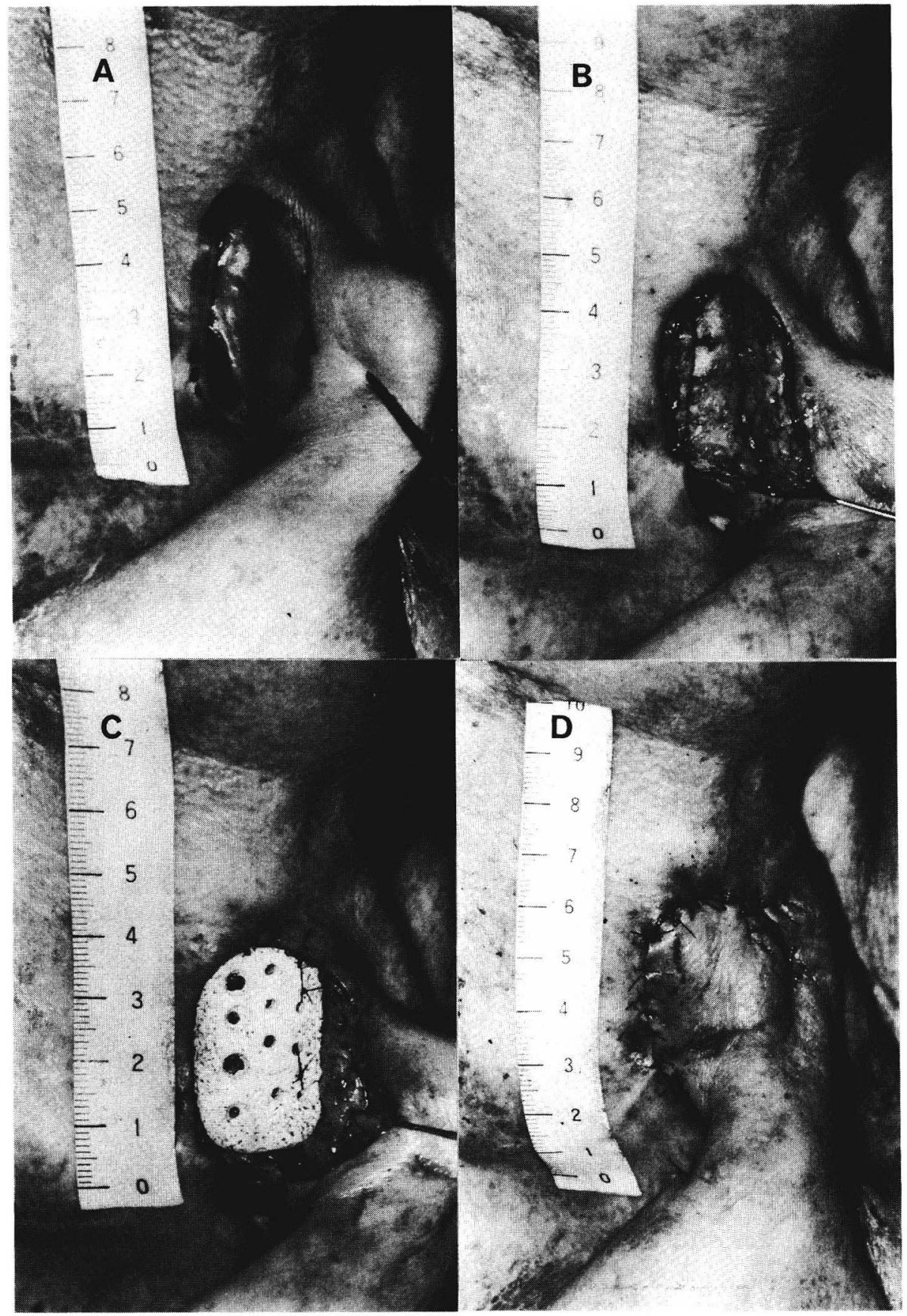

図 2 症例 2 の喉頭気管再建

各写真の上方が頭側。A：術前の喉頭気管孔。線は前壁作製のための切開線 を示す。 $\mathrm{B}$ ：気管前壁の作製。C：アパタイトを前壁の皮弁と縫着固定。D： 創閉鎖終了時。

所見，治療，経過：1985年 1 月29日当科に入 院し, 甲状腺癌 T4N3M0 の診断のもとに, 同年
2 月 4 日甲状腺全摘出術, 両側頸部郭清術を行 なった。この際，第 1 第 3 気管輪の前壁およ 


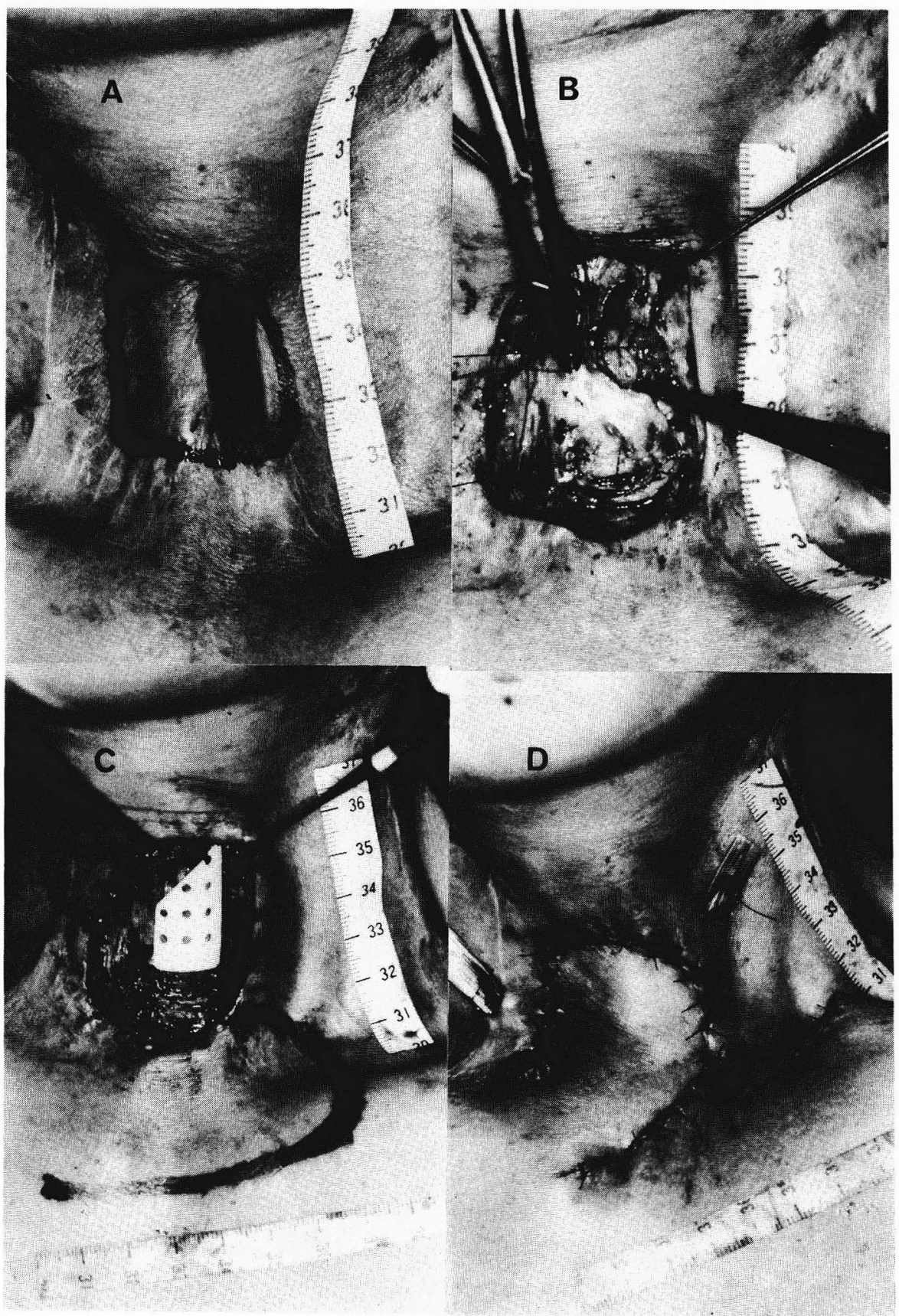

図 3 症例 3 の気管再建

各写真の上方が頭側。 $\mathrm{A}$ : 術前の気管孔。線は前壁作製のための切開線を示 す。 B : 気管前壁の作製。C：アパタイトを前壁の皮弁と縫着固定。線は創閉 鎖のための rotation flapの切開線を示す。 D : 創閉鎖終了時。

び左側壁を癌浸潤のため部分切除し，その欠損 部では気管粘膜と皮膚を縫合し，気管を樋状に
開いておいた。

術後 8 カ月経過した1985年10月17日に，気管 


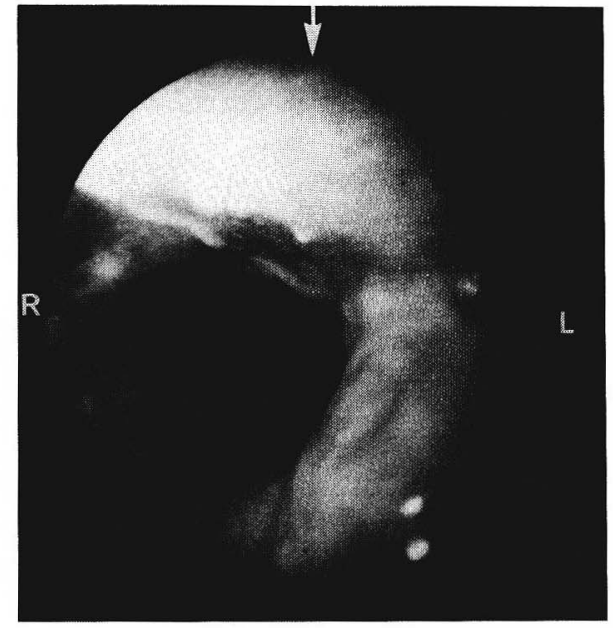

図 4 症例 3 の術後の気管内腔 気管内腔は充分な管腔を示し, 狭窄は認め られない。矢印の部はアパタイトを固定して 再建した気管前壁を示す。 $\mathrm{R}$ は右側壁，Lは 左側壁を示す。

再建を行なった。気管孔の大きさは, 緹 $29 \mathrm{~mm}$, 横 $10 \mathrm{~mm}$ であった (図 $3 \mathrm{~A}$ )。気管孔の両側の 皮膚を hinge flap として用い, 気管の前壁を作 製し(図 3 B), その上に緻密体のアパタイト(旭 光学, 特注品) を置いて固定した (図 $3 \mathrm{C}$ )。用 いたアパタイトは, 縦 $28 \mathrm{~mm}$, 横 $8 \mathrm{~mm}$, 厚さ $1 \mathrm{~mm}$ の大きさで, 曲率半径 $9 \mathrm{~mm}$ の彎曲をも ち, 固定のために直径 $2 \mathrm{~mm}$ の小孔が $3 \mathrm{~mm}$ 間 隔にあらかじめあけてある。頸部の創は rotation flapを用いて閉じた（図 $3 \mathrm{D}$ )。

図 4 は術後約 3 力月経過した時の気管内腔を 示す。術後 5 力月の現在, 再狭窄の所見は認め られない。

\section{症例 4 : K.F. 36歳 男性 \\ 初診：1985年 2 月 18 日 \\ 主訴：呼吸困難}

現病歴： 1 歳 5 カ月の時, 喉頭ジフテリアに 罹患し, 緊急気管切開術を受けた。以来15歳ま で気管カニューレを留置していた。15歳時に気 管孔を閉鎖したが，運動時には呼吸困難を生じ ていた。しかし日常生活には重大な支障がない ため放置していたところ，1984年頃より感冒に 罹患すると呼吸困難が増悪するようになり, 某

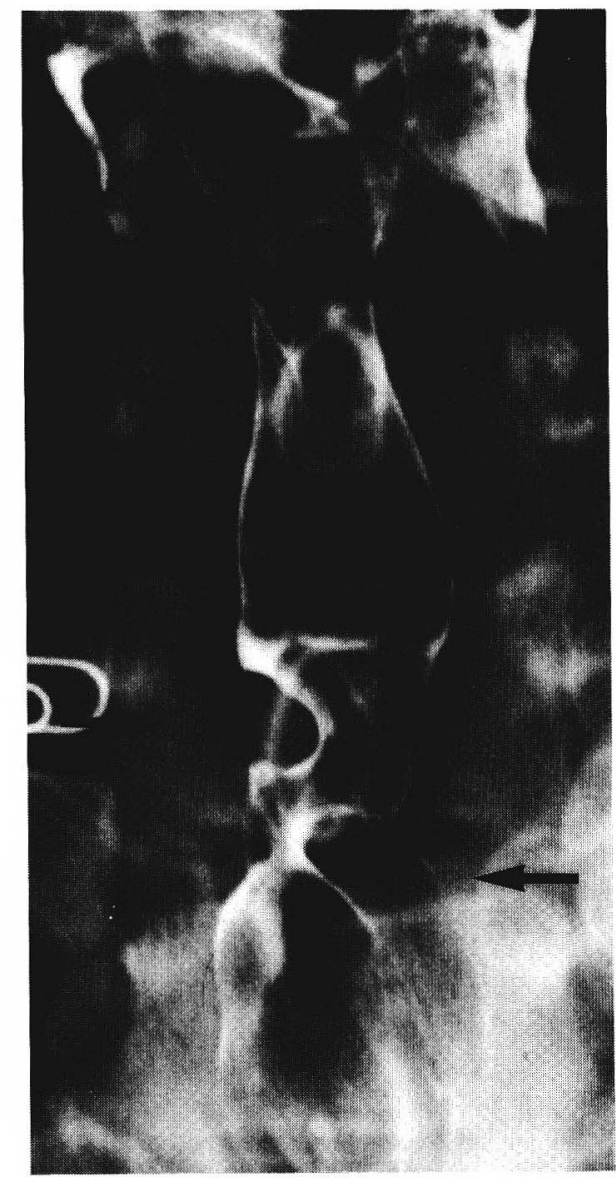

図 5 症例 4 の喉頭気管造影

矢印は左右の気管側壁より突出した気管狭 窄の状態を示す。

病院を受診して当科を紹介された。

所見, 治療, 経過 : 気管狭窄の診断のもとに 1985 年 2 月 27 日当科に入院した。入院時の気管 造影写真を図 5 に示す。気管には, 高さが異な る 2 力所で狭窄が認められた。

1985年 3 月 7 日，まず狭窄部を拡大する手術 を行なった。輪状軟骨より第 6 気管輪にわたつ て，正中で切開を入れ気管内腔を明視下におい た。気管の右壁で第 1 ，第 2 ，第 3 気管軟骨が 著明に気管内腔へ突出し, 左壁では第 4 , 第 5 , 第 6 気管軟骨が内腔へ突出して, その周囲は瘢 痕が著明であった。

気管内腔へ突出している気管軟骨を除去し, 気管粘膜と皮膚を縫合して気管を樋状に開空し 
日気食会報, $38(1), 1987$

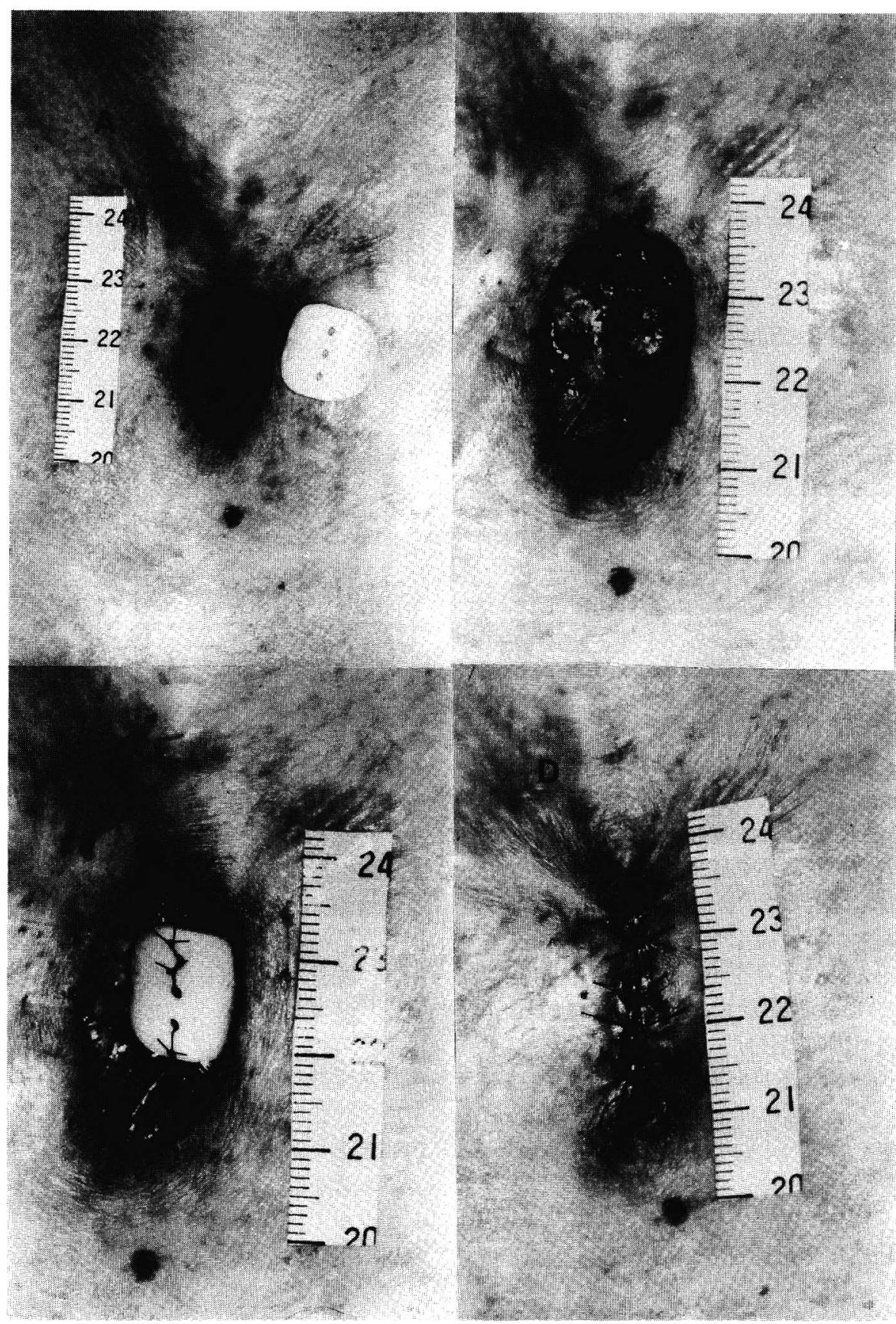

図 6 症例 4 の気管再建

各写真の上方が頭側。A：術前の気管孔。気管孔の側方に挿入するアパタイ 卜が惪いてある。線は前壁作製のための切開線を示す。B：気管前壁の作製。 $\mathrm{C} ：$ アパタイトを前壁の皮弁と縫着固定。D：創閉鎖終了時。

た。気管内には，Tチューブを留置した。Tチ ユーブは約 7 カ月後の10月24日に抜去した。
抜去後, 約 2 力月経過を観察し, 再狭窄をき たさないことを確認して，1985年12月23日気管 
の再建と閉鎖を行なった。術前の気管孔の大き さは, 縦 $14 \mathrm{~mm}$, 横 $10 \mathrm{~mm}$ であった(図 $6 \mathrm{~A}$ )。 気管孔周囲の皮膚を hinge flap として用い, 気管前壁を作製した(図6 B)。その上に緻密体 のアパタイト（旭光学, 特注品) を置き, 小孔 を通して気管前壁に縫着固定した(図 6 C)。用 いたアパタイトは, 繸 $14 \mathrm{~mm}$, 横 $10 \mathrm{~mm}$, 厚さ $1.5 \mathrm{~mm}$ の大きさで, 曲率半径 $8 \mathrm{~mm}$ の彎曲を もち，固定のために直径 $1.5 \mathrm{~mm}$ の小孔が 4 $\mathrm{mm}$ 間隔にあらかじめあけてある。頸部の創 は, 周囲の皮膚を引きょせて閉鎖した(図 $6 \mathrm{D})$ 。

術後 3 力月経過した現在, 再狭窄の所見は認 められない。図 7 は術後31日の気管内腔を示す。 しかし，この患者では，留意すべきことがおこ つた。術直後より患者は, 頸部を前後左右に屈 伸したり，回旋したりする時に，局所の疼痛を 訴えていた。そのため退院後, 体をはげしく動 かす工場現場の作業から事務職に移っている。

\section{症例 5 : T.U. 59歳 女性}

初診：1985年 4 月 30 日

\section{主訴：呼吸困難}

現病歴：1984年 6 月 23 日，交通事故で肋骨お よび大腿骨骨折, 動摇胸, 腎挫創, 結腸間膜損 傷を受け，某病院で28日間にわたる経口挿管を 受けた。抜管後 16 日目に呼吸困難をきたしたた め, 同年 8 月 5 日気管切開術を受けた。しかし 気管カニューレに栓をすると呼吸困難をきたす ので，気管カニューレを留置したままリハビリ テーションを受けていた。

1985年 4 月 17 日, 同じ病院の耳鼻咽喉科に, 呼吸困難の原因精査のため紹介された。喉頭フ アイバースコピーで声門下腔に狭窄を認めら れ，当科を紹介された。

所見，治療，経過：1985年 4 月30日，当科に 入院した。狭窄は声門下腔に全周性に認められ， 気管孔より上方の気管にも狭窄が認められた。

同年 5 月 13 日，甲状軟骨中央の高さから第 6 気管輪にわたって正中で截開し，狭窄を除去し た。輪状軟骨に対しては, posterior cricoid split も併せ行ない，断ち割った後壁は左右に広げて 鼻中隔の composite graft を行なった。気管お よび輪状軟骨は，粘膜と皮膚を縫合し樋状に開 空し，Tチューブを留置した。

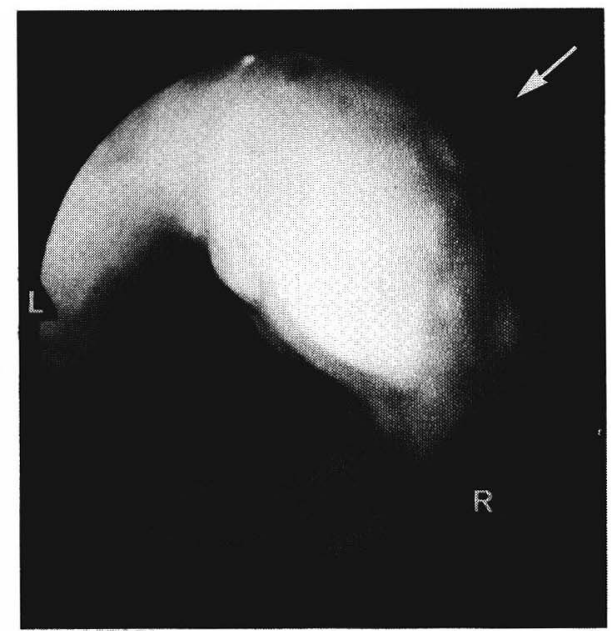

図 7 症例 4 の術後の気管内腔

気管内腔は充分な広さを保持している。矢 印の部はアパタイトを固定して再建した気管 前壁を示す。 $\mathrm{R}$ は右側壁，Lは左側壁を示す。

1986年 2 月 27 日，喉頭および気管の再建と閉 鎖を行なった。喉頭気管孔の大きさは, 縦 48 $\mathrm{mm}$, 横 $7 \mathrm{~mm}$ であった (図 $8 \mathrm{~A}$ )。気管孔周囲 の皮膚を hinge flap として用い，気管前壁を作 製した(図 8 B)。その上に緻密体アパタイト(旭 光学, 特注品)を, 上下 2 力所に $10 \mathrm{~mm}$ 離して 置き, 縫着固定した(図 $8 \mathrm{C}$ )。上方のアパタイ トは甲状軟骨から輪状軟骨のレベルに置いた。 その大きさは, 縦 $21 \mathrm{~mm}$, 横 $18 \mathrm{~mm}$, 厚さ $1 \mathrm{~mm}$ で, 曲率半径 $8 \mathrm{~mm}$ の彎曲をもち, 固定のため に直径 $2 \mathrm{~mm}$ の小孔が $4 \mathrm{~mm}$ 間隔にあらかじ めあけてある。下方のアパタイトは第 4 抢よび 第 5 気管輪のレベルにおいた。その大きさは縦 $9 \mathrm{~mm}$, 横 $24 \mathrm{~mm}$, 厚さ $1 \mathrm{~mm}$ で, 曲率半径 10 $\mathrm{mm}$ の彎曲をもち上方のアパタイトと同じ直 径と間隔の小孔があらかじめあけてある。

アパタイトを上下 2 カ所に分けて離して置い た理由は, 症例 4 に鑑みて, 首の前後屈により 気管前壁の皮膚および皮下組織が伸縮するの で, 硬い大きな 1 枚のアパタイトを插入すると, 首の前後屈が制限され，また運動時に疼痛がお こることを懸念したためである。創は周囲の皮 膚を引きよせて閉鎖した(図 $8 \mathrm{D}$ )。術後 1 力月 の現在，支障は全く訴えていない。 


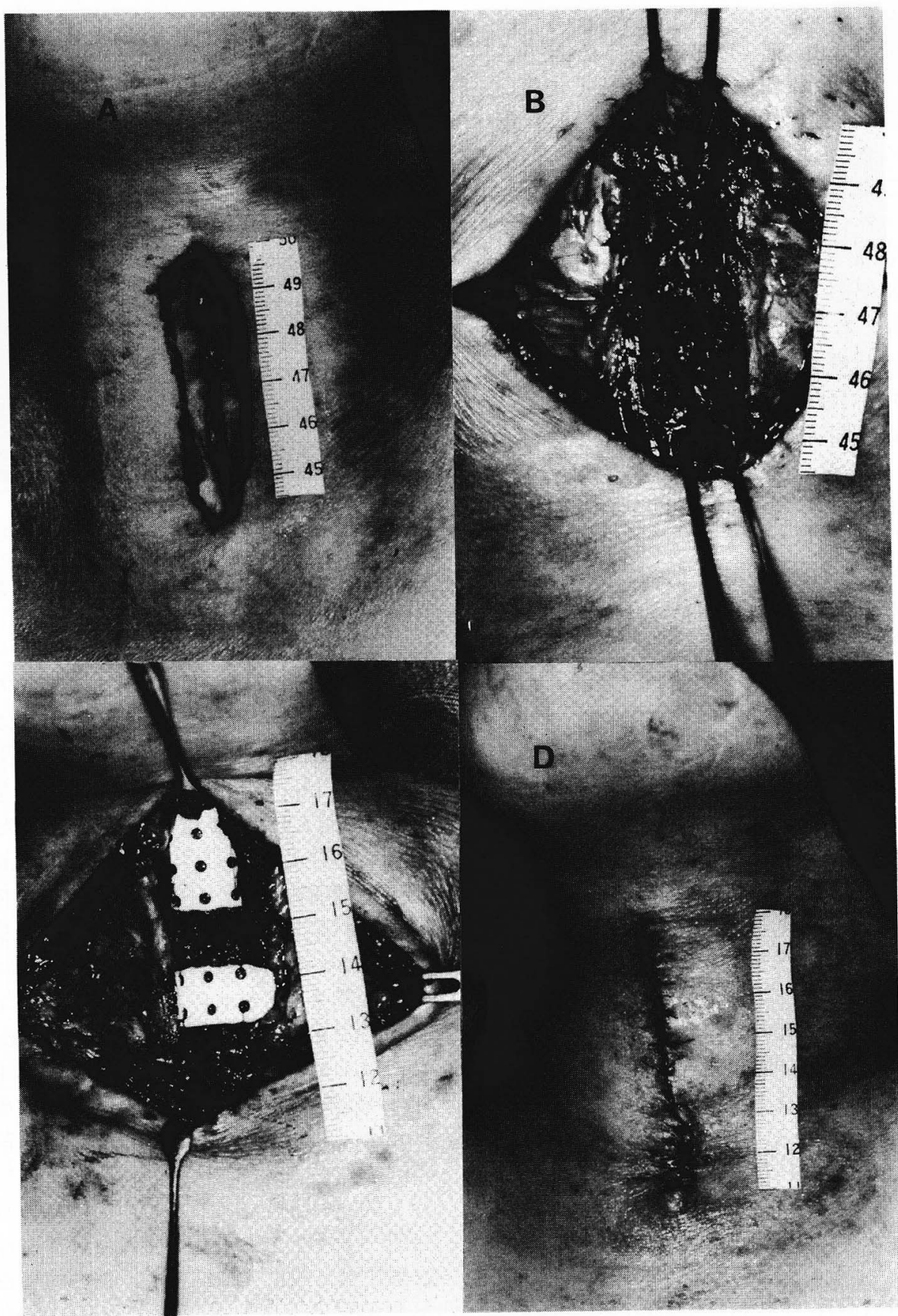

図 8 症例 5 の喉頭気管再建

各写真の上方が頭側。 $\mathrm{A}$ : 術前の気管孔。線は前壁作製のための切開線を示 す。 $\mathrm{B}$ : 気管前壁の作製。 $\mathrm{C}$ : 上下 2 力所にアパタイトを置き前壁の皮弁と縫 着固定。D : 創閉鎖終了時。

\section{総括考按}

喉頭頸部気管狭窄に対する開放手術には，基
本的には次の 4 通りの方法がある。

a . 狭窄部の切除と端々吻合。 
b . 狭窄部の切除と人工気管の挿入（研究段 階)。

c 。狭窄部の拡大，コアモールド留置，一期 的閉鎖。

d. 狭窄部の拡大，桶状開放，コアモールド 留置，二期的閉鎖。

喉頭頸部気管の部分的欠損に対する手術も, 基本的には狭窄部を切除あるいは拡大したあと と同じ考え方で行なわれている。

上記 c , d においては, 軟骨の枠組の欠損が 大きい場合には, その再建が必要である。枠組 の再建に当っては，次のことを考慮せねばなら ない。

(1) 充分な広さの内腔を保持する。

（2）吸息時の陰圧によって喉頭気管壁が陥凹 しない。

(3) 頸部の前後左右への屈伸, 左右への回旋運 動を喉頭気管壁が妨げない。そのためには再建 した気管が，ある程度屈伸できる。

枠組の再建には, 従来, 耳介遊離複合移植 (田 辺 ${ }^{1)}, Z \mathrm{ehm} ら^{2)}$ ), 鼻中隔軟骨 (原田 ${ }^{3)}$ ，奥 田ら ${ }^{4)}$ ), 肋軟骨 (三宅ら ${ }^{5)}$, 今野ら ${ }^{6)}$ ) など, 自 家軟骨が多く用いられている。われわれも鼻中 隔軟骨あるいは胁軟骨を常用していた。

自家軟骨の長所は，組織の拒絶反応がおこら ないことであるが，欠点は身体の他の部位に手 術侵襲を加えることである。自家軟骨と同じ長 所をもつ人工材料があれば，余分の手術侵襲を 避けることができる。

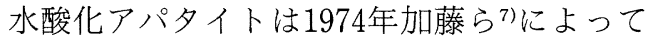
焼結体として合成された。その特徵としては, 骨や歯の無機質成分と同一の結晶構造物で，生 体内では溶解，吸収されることなく，また異物 として認識されないので，感染や異物反応を起 さないといわれている8。

このような特徵をもつ水酸化アパタイトの有 用性については，基礎的研究や臨床的応用の報 告が少なからず行なわれている。たとえば，基 礎的研究としては下顎骨910)，頸骨11)，気管軟 骨 ${ }^{12)}$ との組織親和性が報告されており，臨床的 応用としては下顎 ${ }^{13) 14)}$ ，鼻柱 ${ }^{14)}$, 前頭骨8), 外耳 道後壁 ${ }^{15) 16)}$, 耳小骨15)への有効な利用が報告さ れている。

われわれは喉頭気管の枠組みの再建に，水酸
化アパタイトを用いたところ，前述のようなよ い結果が得られた。

水酸化アパタイトには，多孔体の製品と緻密 体の製品とがある。われわれはこの両者を試用 してみたが，いずれもよく生着し，臨床的には 異物反応は全く認められなかった。ただ形を適 合するための工作は，緻密体の方が容易であっ た。多孔体は緻密体に比べるともろく砕けやす い。緻密体を削る操作は, 滅菌水の中でダイヤ モンド・バーを用いて行なうとよい。

使用する水酸化アパタイトの形と大きさは, これまでは症例毎に欠損部に合わせて調整して いたが，これでは手数が繁雑で気軽に利用でき ない。気管軟骨と同じ形の，曲率半径の違うい く種類かのアパタイト輪を用意しておいて，長 さだけを術中に調整すればよいように検討中で ある。

\section{まとめ}

5 症例において, 喉頭気管の枠組みの再建に 水酸化アパタイトを用い, よい結果を得た。従 来好んで用いられていた自家軟骨と同じように 安全に使用できた。余分の手術侵襲を必要とす る自家軟骨に代わるべき材料と考える。

本論文の要旨は, 第12回北部九州連合学術講演会 （1986年 7 月13日，佐賀市）において口演した。

\section{文 献}

1）田辺正博・他：耳介複合移植片による声門下狭 窄の治療, 日形会誌, $2: 352-358,1982$.

2 ) Zehm, C. et al. : 遊離複合移植による声門下気 管狭窄の治療，耳鼻臨床，70：971-975, 1977.

3 ) 原田康夫・他：鼻中隔軟骨粘膜弁を用いた気道 再建術の 2 症例, 耳鼻臨床, $74: 2142-2150,1981$.

4 ）奥田稔・他：鼻中隔を利用した一次的頸部気管 形成例, 耳喉, 45：439-443, 1973.

5 ）三宅弘・他：気管狭窄に対する硬口蓋粘膜及び 助軟骨利用の拡張手術, 手術, 25：668-673, 1971.

6 ）今野昭義・他：気管壁に浸潤した甲状腺癌切除 後の頸部気管再建術 -1 次的頸部郭清術と併用し 得る術式の検討一, 耳喉, 48：171-183, 1976.

7 ）加藤一男・他：人工骨ならびに人工歯根材料の 展望，化学工業：1262-1268, 1974.

8 ) 熊川孝三・他：アパタイトセラミックスによる 前頭洞骨欠損部の形成，日耳鼻，86：1472-1477, 1983.

9 ）小木曽誠：Apatite 焼結体埋入による顎骨組織 の経時的推移変化, 口病誌, $45: 170-221,1978$. 
10）山崎安晴：人工骨としての多孔質アパタイトー 顎骨補填実験一, 口病誌, 49:41-68, 1982.

11）山崎安晴・他：人工骨としての多孔質アパタイ ト一頸骨埋入実験一, 口病誌, 49:250-278, 1982.

12）大西清・他：多孔質ハイドロキシアパタイトの 人工気管への応用, 人工臟器, $14: 700-703,1985$.

13）塩田重利・他：口腔外科領域におけるハイドロ キシアパタイトの応用, The Quintessence, $4: 43$ $-52,1985$

14）大西正俊・他：人工骨としての多孔質アパタイ ト一臨床応用例を中心として一, 歯科ジャーナル,
$17: 623-633,1983$.

15）船坂宗太郎・他：ハイドロキシアパタイトを利 用した聴器の形態・機能の回復, The Quintessence, 14:380-388, 1985.

16）松本和彦・他：中耳手術におけるアパタイトの 応用, 日耳鼻, 86：288-294, 1983.

(別刷請求： 7830 久留米市旭町 67

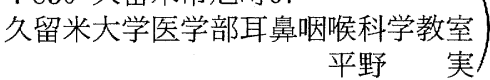

実

（投稿受付 1986 年 4 月17日） 